\title{
The Wreckage of Intentions
}




\section{ALEMBICS: PENN STUDIES IN LITERATURE AND SCIENCE}

Mary Thomas Crane and Henry S. Turner, Series Editors 


\section{THE WRECKAGE \\ OF I N T E N T IONS}

Projects in British Culture, I660-I730

\section{DAVID ALFF}

\section{PENN}


Copyright (C) 2017 University of Pennsylvania Press

All rights reserved. Except for brief quotations used for purposes of review or scholarly citation, none of this book may be reproduced in any form by any means without written permission from the publisher.

\author{
Published by \\ University of Pennsylvania Press \\ Philadelphia, Pennsylvania I9IO4-4II2 \\ www.upenn.edu/pennpress
}

Printed in the United States of America on acid-free paper

$$
\text { IO } 98765432 \text { I }
$$

Library of Congress Cataloging-in-Publication Data

Names: Alff, David, author.

Title: The wreckage of intentions : projects in British culture, 1660-1730 / David Alff.

Other titles: Alembics: Penn studies in literature and science

Description: Ist edition. | Philadelphia : University of

Pennsylvania Press, [2018] | Series: Alembics | Includes

bibliographical references and index.

Identifiers: LCCN 20I7010475 | ISBN 978-0-8I22-4959-O (hardcover : alk. paper)

Subjects: LCSH: English literature—17th centuryHistory and criticism. | English literature-18th century-History and criticism. | Industrial development projects-England-History-17th century. | Industrial development projects—EnglandHistory-18th century. | Scientific literatureEngland-History—I7th century. | Scientific literature-England-History-I8th century. | England-Civilization—-17th century. | EnglandCivilization-18th century.

Classification: LCC PR43I .A39 2017 | DDC 820.9/004

$\mathrm{LC}$ record available at https://lccn.loc.gov/2017010475 
For Katie, as always 
This page intentionally left blank 